\title{
Effect of process variables on the osmotic dehydration of star-fruit slices
}

\author{
Efeito das variáveis de processo na desidratação osmótica de fatias de carambola
}

\author{
Camila Dalben Madeira CAMPOS ${ }^{1}$, Ana Carla Kawazoe SATO ${ }^{1}$, Renata Valeriano TONON ${ }^{1}$, \\ Míriam Dupas HUBINGER ${ }^{1}$, Rosiane Lopes da CUNHA ${ }^{1 *}$
}

\begin{abstract}
The objective of this work was to study the effect of blanching and the influence of temperature, solution concentration, and the initial fruit:solution ratio on the osmotic dehydration of star-fruit slices. For blanching, different concentrations of citric and ascorbic acids were studied. The samples immersed in $0.75 \%$ citric acid presented little variation in color in relation to the fresh star-fruit. Osmotic dehydration was carried out in an incubator with orbital shaking, controlled temperature, and constant shaking at $120 \mathrm{rpm}$. The influence of process variables was studied in trials defined by a complete $2^{3}$ central composite design. In general, water loss and solids gain were positively influenced by temperature and by solution concentration. Nevertheless, lower temperatures reduced water loss throughout the osmotic dehydration process. An increase in the amount of dehydrating solution (initial fruit:solution ratio) slightly influenced the evaluated responses. The process carried out at $50{ }^{\circ} \mathrm{C}$ with a solution concentration of $50 \%$ resulted in a product with lower solids gain and greater water loss. Under these conditions, blanching minimized the effect of the osmotic treatment on star-fruit browning, and therefore the blanched fruits showed little variation in color in relation to the fresh fruit.

Keywords: Averrhoa carambola; blanching; osmotic dehydration; mass transfer.
\end{abstract}

\section{Resumo}

O objetivo deste trabalho foi estudar o efeito do branqueamento e a influência da temperatura, concentração de sacarose e da relação fruta:solução inicial na desidratação osmótica de fatias de carambola. Para o branqueamento, diferentes concentrações de ácido cítrico e ascórbico foram estudadas. As amostras imersas em $0,75 \%$ de ácido cítrico apresentaram pouca variação de cor em relação à carambola fresca. A desidratação osmótica foi conduzida em uma incubadora com agitação orbital, com temperatura controlada e agitação constante de 120 rpm. A influência das variáveis de processo foi avaliada através de ensaios definidos por um planejamento experimental fatorial $2^{3}$ completo. De modo geral, a perda de água e o ganho de sólidos foram influenciados positivamente pela temperatura e pela concentração da solução enquanto que a relação fruta:solução no início da desidratação exerceu pouca influência sobre os parâmetros avaliados. O processamento a baixas temperaturas prejudicou a saída de água ao longo do processo. O processo realizado a $50{ }^{\circ} \mathrm{C}$ e concentração da solução de $50 \%$ resultou em menor ganho de sólidos e maior perda de água. Nesta condição, o branqueamento minimizou o efeito do tratamento osmótico no escurecimento das carambolas, fazendo com que as frutas branqueadas e processadas apresentassem pouca variação de cor em relação à fruta fresca.

Palavras-chave: Averrhoa carambola; branqueamento; desidratação osmótica; transferência de massa.

\section{Introduction}

Star-fruit (Averrhoa carambola) is a fruit originated in tropical Asia. Nowadays, it is produced throughout Brazil and the State of São Paulo is the main producer. Currently most of the star-fruit is commercialized as fresh fruit, although there is a considerable interest in commercializing it as pre-cut or sliced fruit, mainly due to its star shape, much used in decorating dishes. It is a source of many nutrients, but its fragility and high moisture content facilitate its deterioration, resulting in a limited shelf life (SHIGUEMATSU et al., 2005).

Drying is a method widely used in the preservation of postharvested fruits and in the production of dehydrated foods. However, conventional drying methods demand considerable energy consumption, since they involve simultaneous heat and mass transfers. This increases process costs, since energy sources are increasingly expensive over the world (FERNANDES et al., 2006). Moreover, the use of high temperatures can result in the degradation and oxidation of some food nutrients. Thus osmotic dehydration stands out as an efficient pre-treatment, improving the final product's quality, due to a reduction in nutrients degradation such as vitamins and minerals. It also shows other advantages such as energy saving (reduction in drying time) and the fact that the product is processed in a liquid phase, allowing for good heat and mass transfer coefficients (RAOULT-WACK, 1994).

Osmotic dehydration is a process based on the immersion of a food, either whole or in pieces, in hypertonic solutions, promoting a simultaneous water loss and solutes penetration into the food. This process results in products with high

Received 2/9/2010

Accepted 28/7/2011 (005026)

${ }_{1}$ Department of Food Engineering, Faculty of Food Engineering, State University of Campinas - UNICAMP, CP 6121, CEP 13083-862, Campinas, SP, Brazil,

e-mail: rosiane@fea.unicamp.br

${ }^{*}$ Corresponding author

http://dx.doi.org/10.1590/S0101-20612012005000034 
nutritional and sensory quality due not only to the partial water removal but also to the protective effect of the solute used (ALZAMORA et al., 1997). As compared to other dehydration methods, this process causes less damage to the cell wall and to the heat labile nutritive components, pigments and aromas, since it demands lower temperatures (RAOULT-WACK, 1994; MATUSEK; CZUKOR; MERESZ, 2008).

Factors such as the fruit:solution ratio, temperature, solution concentration, agitation level and processing time and temperature can influence the mass transfer of water and solutes in the osmotic dehydration process. Temperature is one of the most important parameters in the osmotic dehydration kinetics. In general, the higher the process temperature, the greater the mass transfer rate, mainly due to the increase in cell permeability. On the other hand, temperatures above $45^{\circ} \mathrm{C}$ can cause undesirable changes in color, flavor and aroma, as well as changes in the food cell wall (TORREGIANI, 1993). An increase in the dehydrating solution concentration can also favor mass transfer, such that the use of highly concentrated syrups close to saturation can promote an increase in the water loss (TORREGIANI, 1993). In most cases this solution ends up being discarded after dehydration, and thus it is of interest to increase the fruit:solution ratio as much as possible, resulting in a more interesting process from the economic point of view.

Another considerable limitation to the production of sliced star-fruit is browning, even after dehydration, since it occurs quickly after exposition to oxygen (WELLER et al., 1997). One alternative aimed at minimizing this problem would be the application of blanching by exposure to heat or immersion in organic acids or salts (MANO-FRANCIS; BRADRIE, 2004).

Thus the objective of the present work was to study the influence of blanching with acid solutions and to evaluate the effect of some process variables (temperature, solution concentration and initial fruit:solution ratio) on the water loss, solutes incorporation and color of osmotically dehydrated star-fruit slices.

\section{Material and methods}

\subsection{Material}

Star-fruits (Averrhoa carambola) of the variety sour, obtained from producers in the region of Campinas-SP Brazil, were used as raw material. The fruits were first visually selected (yellow with green extremities), at the fully grown almost ripe stage, and subsequently by the soluble solids content ( 9 to $10{ }^{\circ}$ Brix).

The osmotic solutions were prepared using commercial sucrose União (Copersucar, Brazil) and distilled water. Anhydrous citric acid, PA-ACS (Synth, Brazil), and L-ascorbic acid USP (Nuclear, Brazil) were used to prepare the blanching solutions.

\subsection{Methods}

\section{Blanching}

One centimeter $(1.0 \mathrm{~cm})$ thick star-fruit slices were blanched by immersion in solutions with different concentrations of citric $(0-1.5 \% \mathrm{w} / \mathrm{w})$ and ascorbic $(0-0.5 \% \mathrm{w} / \mathrm{w})$ acids, at room temperature for 15 minutes. The treatments were carried out according to a complete $2^{2}$ central composite rotatable design with 4 factorial points, 4 axial points, and 3 central points resulting in a total of 11 trials (Table 1). A control sample was immersed in pure distilled water in order to evaluate the browning of non-treated fruits, and another sample was cut at the moment of the test to compare the results with those of the fresh fruit.

After blanching, the fruits were drained and exposed to ambient conditions for 6 hours. They were then instrumentally analyzed in terms of color using a Color Quest II bench spectrophotometer (Hunter Lab, Reston, USA) with 6 readings for each sample. The equipment was calibrated with Specular Reflectance Included (RSIN) using the white $(X=77.46$; $\mathrm{Y}=82.08 ; \mathrm{Z}=88.38)$ and grey $(\mathrm{X}=47.71 ; \mathrm{Y}=50.83 ; \mathrm{Z}=54.94)$ standards, a $10^{\circ}$ angle, and the D65 light source. The CieLab coordinates $\left(a^{*}, b^{*}, L^{*}\right)$ were read directly on the equipment, and the total color difference $\left(\Delta E^{*}\right)$ in relation to the just-cut fruit was calculated according to Equation (1).

$$
\Delta \mathrm{E}^{*}=\sqrt{\left(\Delta \mathrm{L}^{*}\right)^{2}+(\Delta \mathrm{a} *)^{2}+\left(\Delta \mathrm{b}^{*}\right)^{2}}
$$

Where:

$$
\Delta L^{*}=\text { variation in luminosity; }
$$

$\Delta a^{*}=$ variation in the hue parameter - from red (+) to green (-); and

$\Delta b^{*}=$ variation in the hue parameter - from yellow $(+)$ to blue (-).

The best blanching condition was considered to be the one that presented the least color variation in relation to the just-cut fruit. This condition was used to evaluate the effect of blanching on the osmotic dehydration of star-fruit, which was carried out according to the conditions defined by the experimental design described in the following section.

\section{Osmotic dehydration}

The fruits, previously selected and washed in tap water, were cut into $1 \mathrm{~cm}$ thick slices and subjected to osmotic dehydration

Table 1. Definition of the independent variables (real and coded) used in the blanching pre-treatments based on the complete experimental design.

\begin{tabular}{ccc}
\hline Condition & Citric acid (\%) & Ascorbic acid (\%) \\
\hline 1 & $0.22(-1)$ & $0.07(-1)$ \\
2 & $1.28(+1)$ & $0.07(-1)$ \\
3 & $0.22(-1)$ & $0.43(+1)$ \\
4 & $1.28(+1)$ & $0.43(+1)$ \\
$5(\mathrm{~A})^{\star}$ & $0(-1.41)$ & $0.25(0)$ \\
$6(\mathrm{~A})^{*}$ & $1.5(+1.41)$ & $0.25(0)$ \\
$7(\mathrm{~A})^{\star}$ & $0.75(0)$ & $0(-1.41)$ \\
$8(\mathrm{~A})^{\star}$ & $0.75(0)$ & $0.5(+1.41)$ \\
$9-11(\mathrm{C})^{* *}$ & $0.75(0)$ & $0.25(0)$ \\
\hline
\end{tabular}

${ }^{*}(\mathrm{~A})$ axial points, ${ }^{* *}(\mathrm{C})$ central points 
under different conditions of temperature $(\mathrm{T})$, concentration (C), and initial fruit:solution ratio (F:S) according to a complete $2^{3}$ central composite design with 8 factorial points, 6 axial points, and 4 central points resulting in a total of 18 trials (Table 2). The process was carried out at a controlled temperature TE- 420 orbital shaker (Tecnal, Piracicaba, Brazil), with constant shaking at $120 \mathrm{rpm}$ (FERRARI et al., 2005; PEREIRA; CARMELLOGUERREIRO; HUBINGER, 2009) and a maximum process time of 8 hours. The samples were submerged in the osmotic solution in $600 \mathrm{~mL}$ beakers separately for each pre-determined time intervals. At the programmed intervals, the beakers were removed, and the samples were rinsed with distilled water and placed on absorbent paper to remove excess solution. The samples were then weighed and taken for determination of weight loss, soluble solids content, water activity, and moisture content.

The mass of the fresh and processed samples was determined using an AM5500 Marte semi-analytical balance (Impac, São Paulo, Brazil). Total soluble solids content was determined by direct reading using a bench refractometer (Zeiss, Jena, Germany), and water activity was measured using a CX-2 Aqualab digital hygrometer (Decagon Devices Inc., Pullman, USA). The moisture content was quantified gravimetrically using a vacuum oven at $60^{\circ} \mathrm{C}$ to constant weight (ASSOCIATION..., 1995). All physicochemical analyses were carried out at least in triplicate.

\section{Data analysis}

The values for solids gain $(S G)$ and water loss $(W L)$ were calculated according to Equations 2 and 3, respectively:

$S G(\%)=\left(\frac{\mathrm{TSS}_{\mathrm{t}} \cdot \mathrm{M}_{\mathrm{t}}-\mathrm{TSS}_{0} \cdot \mathrm{M}_{0}}{\mathrm{M}_{0}}\right) \times 100$

Table 2. Definition of the levels of the independent variables used in the osmotic dehydration trials based on a complete experimental design with three variables - coded values in brackets.

\begin{tabular}{lccc}
\hline Trials & $\begin{array}{c}\text { Temperature } \\
\left({ }^{\circ} \mathrm{C}\right)\end{array}$ & $\begin{array}{c}\text { Solution } \\
\text { concentration }(\%)\end{array}$ & $\begin{array}{c}\text { Initial } \\
\text { fruit:solution ratio }\end{array}$ \\
\hline 1 & $30(-1)$ & $35(-1)$ & $1: 5.0(-1)$ \\
2 & $50(+1)$ & $35(-1)$ & $1: 5.0(-1)$ \\
3 & $30(-1)$ & $55(+1)$ & $1: 5.0(-1)$ \\
4 & $50(+1)$ & $55(+1)$ & $1: 5.0(-1)$ \\
5 & $30(-1)$ & $35(-1)$ & $1: 2.5(+1)$ \\
6 & $50(+1)$ & $35(-1)$ & $1: 2.5(+1)$ \\
7 & $30(-1)$ & $55(+1)$ & $1: 2.5(+1)$ \\
8 & $50(+1)$ & $55(+1)$ & $1: 2.5(+1)$ \\
$9(\mathrm{~A})^{*}$ & $40(0)$ & $45(0)$ & $1: 7.6(-1.68)$ \\
$10(\mathrm{~A})^{*}$ & $40(0)$ & $45(0)$ & $1: 2.1(+1.68)$ \\
$11(\mathrm{~A})^{*}$ & $40(0)$ & $28.2(-1.68)$ & $1: 3.3(0)$ \\
$12(\mathrm{~A})^{*}$ & $40(0)$ & $61.8(+1.68)$ & $1: 3.3(0)$ \\
$13(\mathrm{~A})^{*}$ & $23.2(-1.68)$ & $45(0)$ & $1: 3.3(0)$ \\
$14(\mathrm{~A})^{*}$ & $56.8(+1.68)$ & $45(0)$ & $1: 3.3(0)$ \\
$15-18(\mathrm{C})^{* *}$ & $40(0)$ & $45(0)$ & $1: 3.3(0)$ \\
\hline
\end{tabular}

${ }^{\star}(\mathrm{A})$ axial points, ${ }^{* *}(\mathrm{C})$ central points
$\mathrm{WL}(\%)=\left(\frac{\mathrm{X}_{0} \cdot \mathrm{M}_{0}-\mathrm{X}_{\mathrm{t}} \cdot \mathrm{M}_{\mathrm{t}}}{\mathrm{M}_{0}}\right) \times 100$

Where:

$X=$ moisture content (wet basis) of the samples $(\mathrm{g} / \mathrm{g}$ )

$M=$ sample mass $(\mathrm{g})$;

TSS $=$ total soluble solids content $\left({ }^{\circ}\right.$ Brix $)$

The sub-indices ${ }_{0}$ and ${ }_{t}$ represent the process at the start and after a time $t$, respectively.

The results for moisture and solid contents obtained in each trial were fitted to Peleg's equation (PELEG, 1988) (Equation 4), an empirical model that has been used by some researchers to describe the osmotic dehydration kinetics (ATARÉS; CHIRALT; GONZÁLEZ-MARTÍNEZ, 2008; AZOUBEL; MURR, 2004; PARK et al., 2002).

$\overline{\mathrm{MC}(\mathrm{t})}=\mathrm{MC}_{0} \pm \frac{\mathrm{t}}{\mathrm{k}_{1}+\mathrm{k}_{2} \mathrm{t}}$

Where:

$\overline{\mathrm{MC}(\mathrm{t})}=$ water or solids' amount at instant $t(\mathrm{~g})$;

$M C_{0}=$ initial water or solids amount $(\mathrm{g})$

$k_{1}, k_{2}=$ Peleg's parameters

$t=$ time (hour).

According to Peleg (1988), the parameter $1 / k_{1}$ is related to the initial rate of mass exchange according to Equation 5:

$\frac{\mathrm{dMC}}{\mathrm{dt}}=\frac{1}{\mathrm{k}_{1}}$

The results of the central composite rotatable design were evaluated statistically using the software STATISTICA ${ }^{\circledR} 5.0$ (Statsoft, Tulsa, USA) and Minitab 15 (Minitab Inc., State College, USA) to obtain the models and evaluate the interactions between the different process parameters.

\section{Results and discussion}

\subsection{Blanching}

The results of the blanching tests did not allow for a good adjustment of the proposed experimental design presenting low determination coefficients $\left(\mathrm{R}^{2}\right)$, which could be attributed to the heterogeneity of the fresh fruits despite the initial selection of the raw material used. Thus, neither the models nor the response surfaces could be obtained to represent the influence of citric and ascorbic acid concentrations on the color parameters under study, and only the behavior of luminosity $\mathrm{L}^{*}$ and total color variation in relation to the fresh fruit $\left(\Delta \mathrm{E}^{\star}\right)$ of the blanched and non-blanched (control) star-fruits were evaluated (Figure 1).

With respect to the luminosity $L^{*}$ (Figure 1a), the non-treated fruits showed a lower value for $\mathrm{L}^{*}$ indicating the browning of the fruits immersed in pure distilled water. In general, all treatments led to a reduction in browning of the star-fruit (higher $\mathrm{L}^{\star}$ when compared to the values obtained for the non-treated fruit), independently of the acid concentration used, with the exception of sample number 1 , which exhibited luminosity values similar to 

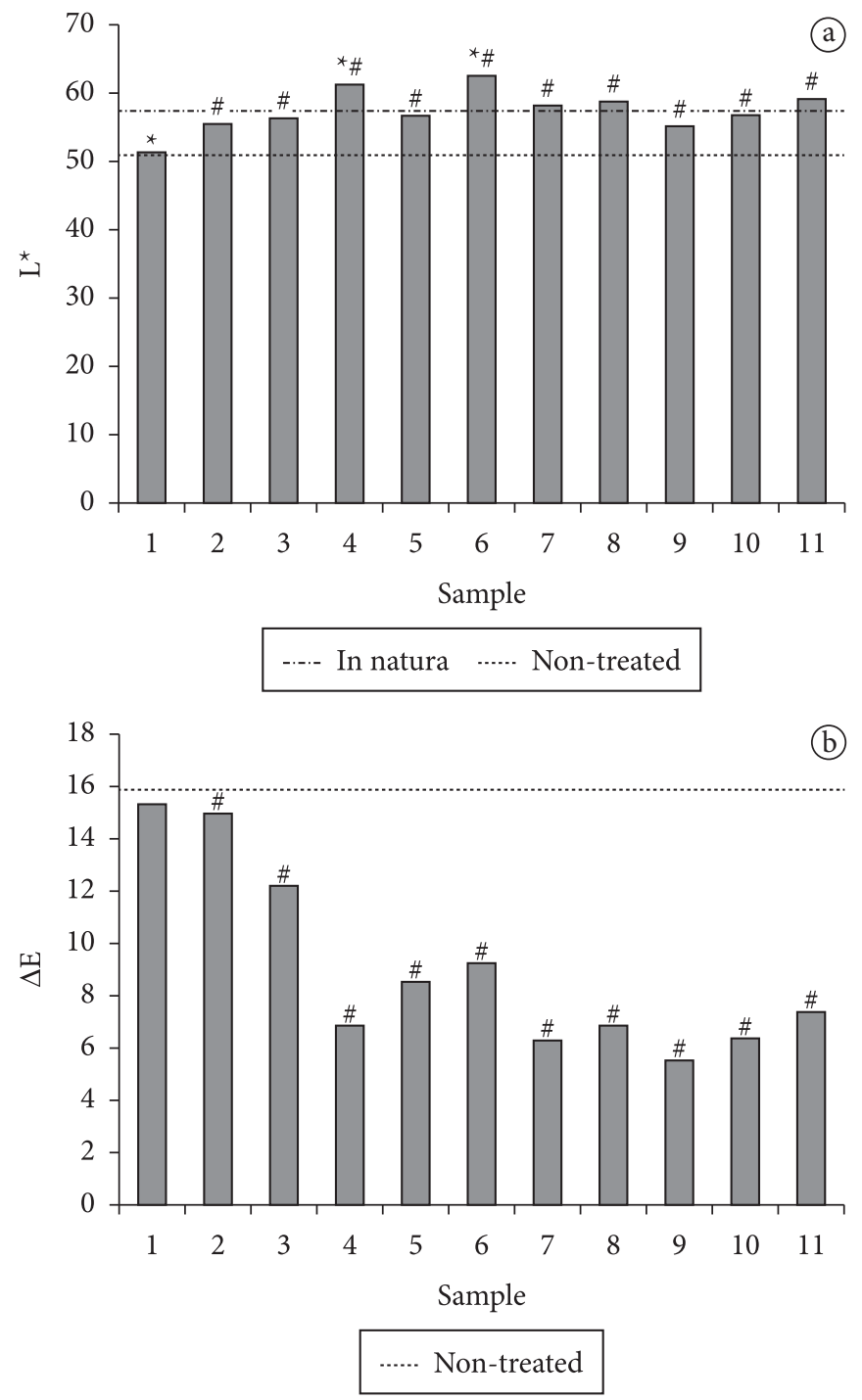

Figure 1. Color parameters for the blanched star-fruit slices and comparisons with the just-cut (---.) and non-treated (----) samples: a) variation in the parameter luminosity $L^{*}$; and $b$ ) total color variation $\Delta \mathrm{E}^{\star}$. ${ }^{\star}$ indicates a significant difference $(\mathrm{p}<0.05)$ in relation to the just-cut fruit; \# indicates a significant difference $(p<0.05)$ in relation to the non-treated fruit.

that of the non-treated sample ( $p>0.05)$. It must be emphasized that this condition, which was not efficient in avoiding fruit browning, was the one in which the samples were treated with the lowest concentration of both acids.

Smaller values for $\Delta \mathrm{E}$ indicate a smaller variation in color in relation to the fresh fruit and therefore lower browning. Amongst the samples treated with the different acid combinations, it can be seen that, as observed for luminosity, sample 1 showed the highest total color variation and was more similar to the nontreated samples. In general, treatments $4,7,8$, and the central points showed the lowest $\Delta \mathrm{E}$ values and were considered the most efficient under the conditions studied (Figure 1b). Thus, considering that citric acid is currently cheaper than ascorbic acid, condition 7 ( $0.75 \%$ citric acid $)$ could be indicated as the most economic treatment and was thus used in all the treatments for further studies.

\subsection{Osmotic dehydration}

\section{Osmotic dehydration kinetics}

The values for water activity $\left(\mathrm{a}_{\mathrm{w}}\right)$ of the dehydrated star-fruit samples at the end of the eight-hour treatment varied between 0.934 and 0.940 , representing a decrease of $5.5 \pm 0.36 \%$ in relation to the initial $\mathrm{a}_{\mathrm{w}}$ of the fruit $(0.992 \pm 0.001)$. Such results are in agreement with those obtained by Alzamora et al. (1997) for samples of various fruits after reaching equilibrium in the osmotic dehydration process.

Figures 2 and 3 show the moisture and soluble solids content of the star-fruit samples with time, for the trials referring to the central and axial points of the experimental design, allowing one to observe the influence of the variation of each parameter on the osmotic dehydration of the star-fruit slices, individually.

In most of the cases, the rates of water removal and solute penetration were higher in the initial stage of the process due to the greater dehydration driving force between the food and the hypertonic solution (LENART, 1996). Thus, osmotic dehydration of the star-fruit slices was faster during the first two hours. Ferrari et al. (2005), Betoret et al. (2004) and Sanjinez-Argandoña (1999), investigating the osmotic dehydration of melon, cassava, and guava, respectively, also observed that the mass transfer occurred more intensely during the first two hours of treatment reaching equilibrium after eight hours of processing.

Evaluating only the points in which a variation in the initial fruit:solution (F:S) ratio occurred (trials 9, 10, and the central points), it can be observed that the highest moisture content values were found for the points with the highest $F: S$ ratio (1:2.1), i.e., the water loss observed in the processes carried out with a smaller amount of solution was lower. This could be attributed to the fact that the osmotic solution was diluted by the water removed from the product resulting in a smaller concentration gradient and, consequently, a reduced water loss. Sousa et al. (2003) also observed greater water loss and solids gain when they reduced the fruit:syrup proportion from 1:2 to $1: 4$ after 1.5 hours of osmotic dehydration of bananas under vacuum. However, when the process was carried out at atmospheric pressure, the increase in the fruit:syrup proportion did not result in significant differences in the water loss or solids gain.

Regarding the influence of temperature on water loss (trials 13,14 , and the central points), it was shown that an increase in this variable caused a considerable reduction in the final moisture content of the fruit. In addition, at temperatures close to the environmental temperature $\left(26.4{ }^{\circ} \mathrm{C}\right)$, the process tended to reach equilibrium quicker due to higher final moisture content. Pérez-Tello et al. (2001), Bauchot et al. (1999) and Ferrari et al. (2005) evaluated the effect of temperature on the osmotic dehydration of star-fruit, kiwi, and melon, respectively, and reported that some alterations can occur at higher temperatures such as swelling and plasticization of the cell membrane, which make the fruits more permeable to the passage of water and entrance of solids. In addition, an increase in temperature results in a decrease in the viscosity of 


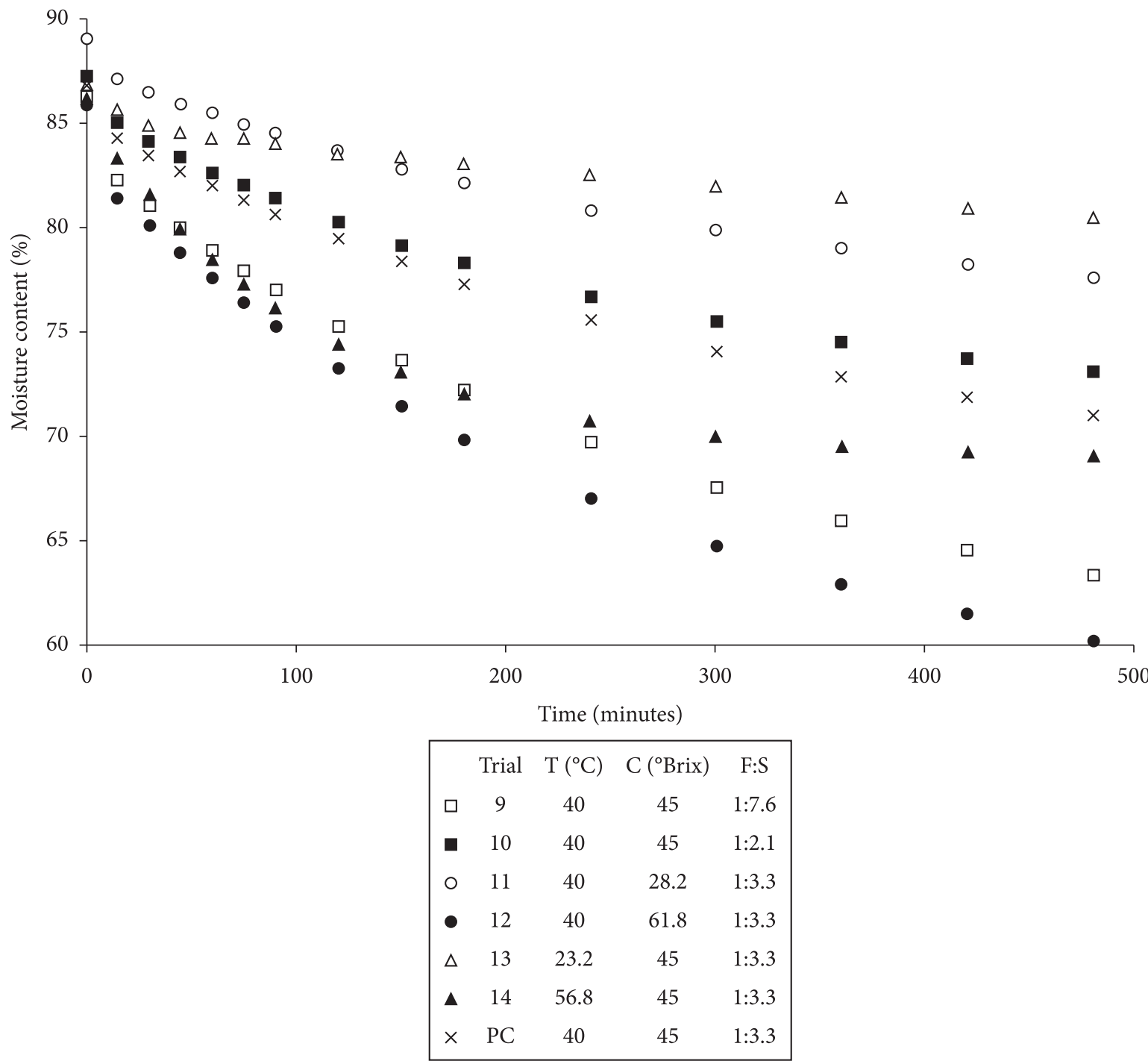

Figure 2. Moisture content as a function of process time for the central and axial points of the experimental design. $\mathrm{T}=$ temperature; $\mathrm{C}=$ concentration, and $\mathrm{F}: \mathrm{S}=$ initial fruit:solution ratio.

the osmotic solution reducing the external resistance to mass transfer (CUSSLER, 1997).

The increase in the osmotic solution concentration (trials 11,12 , and the central points) also led to an increase in water loss and solids gain of the star-fruit samples, which could be explained by the greater concentration gradient between the fruit and the solution resulting in a greater dehydration driving force, which was also observed by Teles et al. (2006) in the osmotic dehydration of melons at $65^{\circ} \mathrm{C}$.

\section{Mass transfer rate}

Table 3 shows the values of the Peleg's parameters adjusted to the osmotic dehydration kinetics data. The values of the parameter $\mathrm{k}_{1}$ are in the range from 0.05 to 4 hours, while $\mathrm{k}_{2}$ ranges between 0.01 to 0.1 for both water and sugars, respectively. Considering that $1 / \mathrm{k}_{1}$ is related to the initial rate of mass exchange, it can be observed that at the highest temperature (trial 14), the initial mass exchange (lowest $\mathrm{k}_{1}$ ) of both water and sugar was faster. This is probably due to the swelling and plasticization suffered by the cell membrane during osmotic dehydration at higher temperatures, which led to an increase in its permeability (UDDIN; AINSWORTH; IBANOGLU, 2004) and a reduction in the viscosity of the osmotic solution (CHENLO et al., 2002).

Considering the fruit composition in equilibrium, it can be observed that the condition with the highest sucrose concentration (trial 12) resulted in samples with lowest $k_{2}$, i.e. with higher sugar intake and water loss in equilibrium.

The models obtained for the parameter associated to the mass exchange rate $\left(1 / k_{1}\right)$ adjusted to the central composite design did not present good fit $\left(\mathrm{R}^{2}<0.6\right)$ for either water or sugar content. Therefore, the response surfaces could not be obtained, and a simple evaluation of the interaction between the process variables on these parameters was made using the software Minitab 15 (Minitab Inc., State College, USA). Figure 4 shows these interactions. 


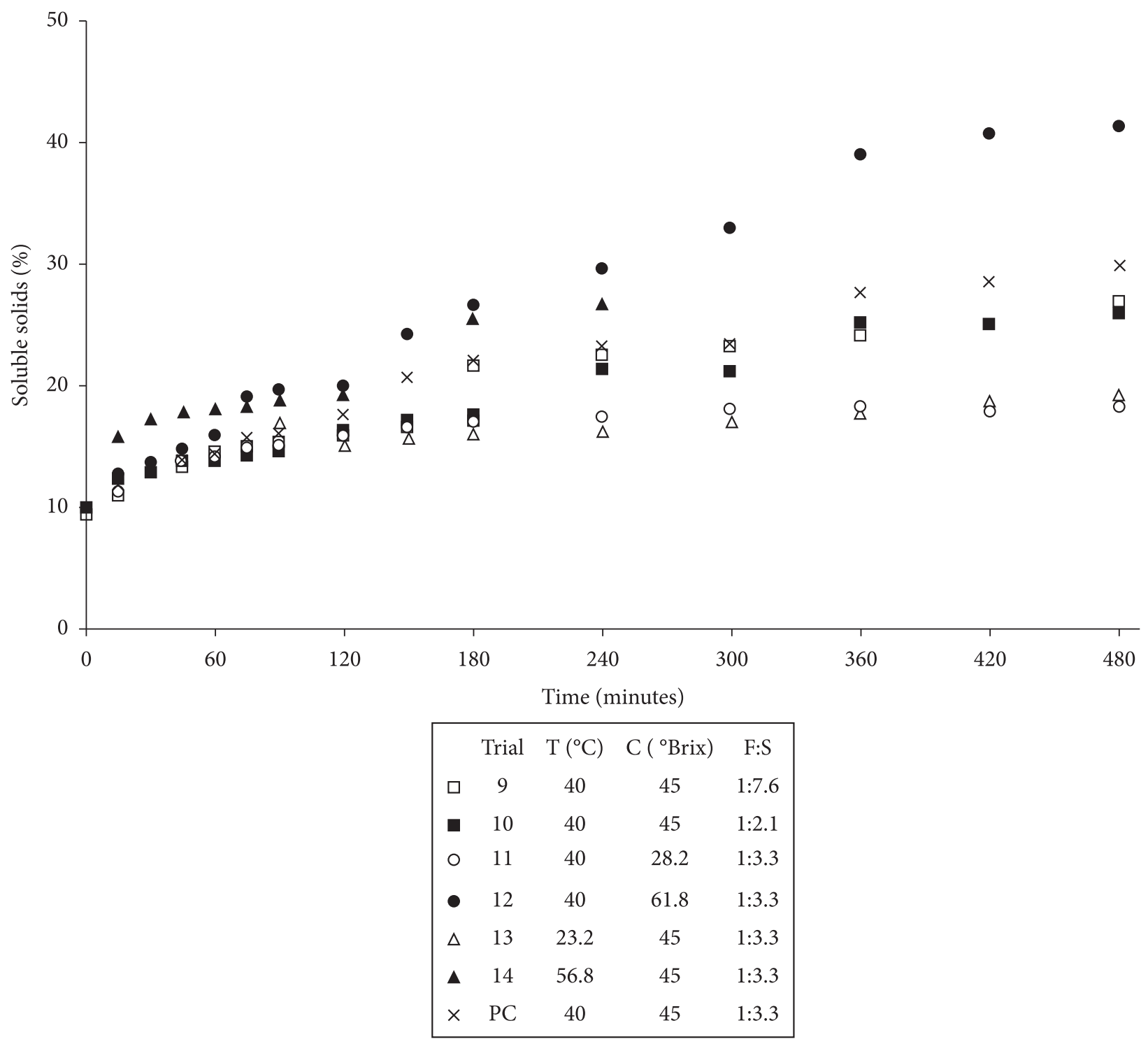

Figure 3. Soluble solids content as a function of process time for the central and axial points of the experimental design. $\mathrm{T}=$ temperature; $\mathrm{C}=$ concentration, and $\mathrm{F}: \mathrm{S}=$ initial fruit:solution ratio.

Generally, it can be observed that increasing the temperature from a minimum $(-1)$ to a maximum level $(+1)$ leads to an increase in the initial mass rate exchange $\left(1 / \mathrm{k}_{1}\right)$ (Figure $4 \mathrm{a}$ and $\mathrm{b}$ ), which is more pronounced at higher osmotic solution concentration $(\mathrm{C}=+1)$. Thus, when smaller solution concentrations (level -1 ) were used, the temperature exerted a less pronounced effect on mass rate exchange compared to that exerted by more concentrated solutions (level +1 ) (Figure 4). In this case, the increase in the solution concentration caused an increase in the osmotic gradient and, consequently, a faster water loss leading to greater diffusivity values. Moreover, the solution viscosity decreases exponentially with temperature (QUINTAS et al., 2006), which may facilitate mass transfer phenomena. Considering the influence of initial fruit:solution ratio, the almost parallel lines observed in Figure 4 indicates no significant effect of interaction between this variable and the solution concentration on the initial mass rate exchange.

\section{Optimization of the osmotic dehydration process}

Since larger values for water loss were obtained in the first 120 minutes, this period of time was used to optimize the osmotic dehydration process. The experimental data for water loss (WL) and solids gain (SG) obtained after 120 minutes were subjected to an analysis of variance (ANOVA) and $\mathrm{F}$ test in order to be fitted to a polynomial of the type Equation 6:

$$
\begin{aligned}
& Y=\beta+\beta_{T} T+\beta_{C} C+\beta_{F} F+\beta_{T T} T^{2}+\beta_{C C} C^{2}+ \\
& +\beta_{F F} F^{2}+\beta_{T C} T C+\beta_{T F} T F+\beta_{C F} C F
\end{aligned}
$$

where $\beta$ is the regression coefficients referring to the variables of temperature (lower case index T), concentration (lower case index $\mathrm{C}$ ), and initial fruit:solution ratio (lower case index $\mathrm{F}$ ); $Y$ is the response in question ( $W L$ or $S G$ ) and $T, C$, and $F$ are the coded independent variables (temperature, solution composition, and initial fruit:solution ratio, respectively). 


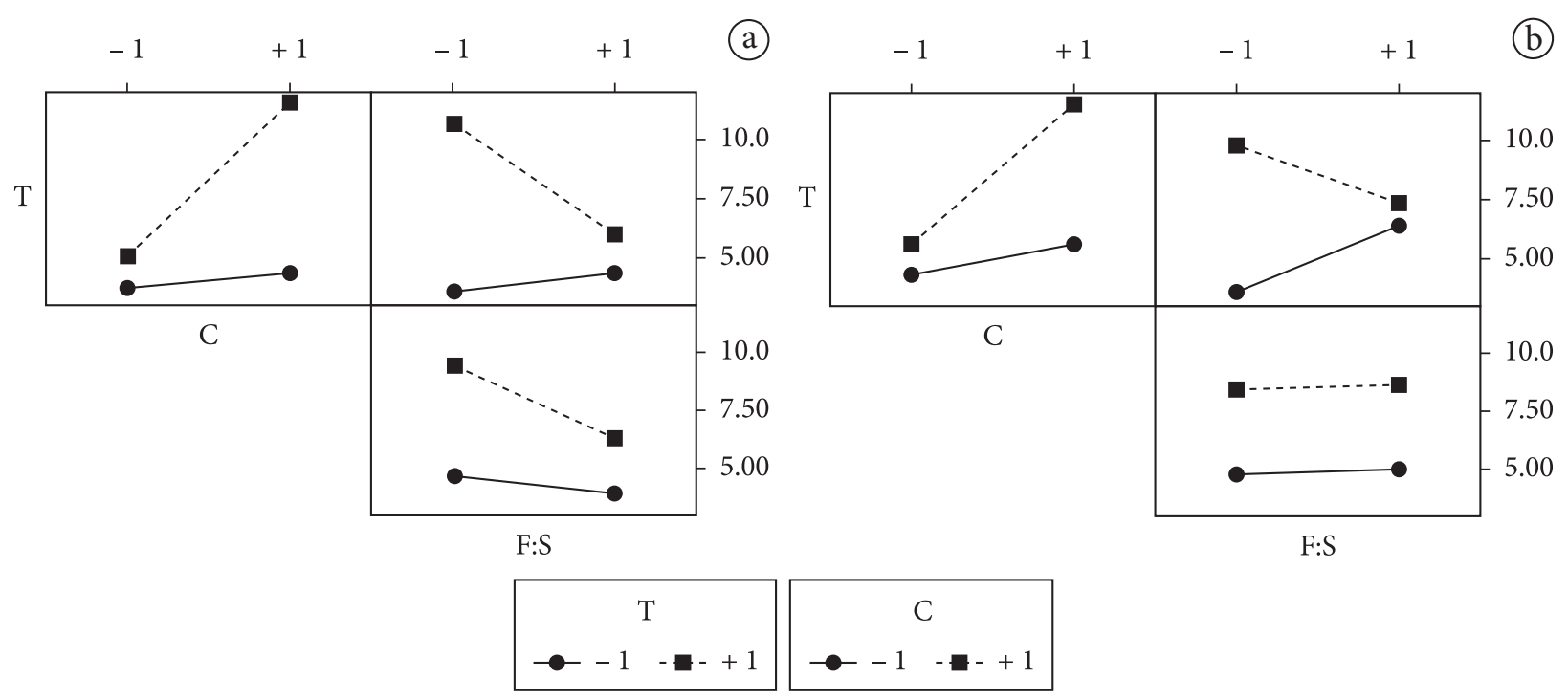

Figure 4. Interaction between the variables studied in the experimental design $(\mathrm{T}=$ temperature; $\mathrm{C}=$ concentration and $\mathrm{F}: \mathrm{S}=$ the initial fruit:solution ratio) for parameter $1 / \mathrm{k}_{1}$ for a) moisture; and $\mathrm{b}$ ) sugar.

Table 3. Peleg's parameters $\left(\mathrm{k}_{1}\right.$ and $\left.\mathrm{k}_{2}\right)$ fitted for moisture and solids content for the different points of the experimental design.

\begin{tabular}{cccccccc}
\hline \multirow{2}{*}{ Trials } & \multicolumn{3}{c}{ Moisture content } & & \multicolumn{3}{c}{ Solids content } \\
\cline { 2 - 4 } \cline { 6 - 8 } & $\mathrm{k}_{1}(\mathrm{~h})$ & $\mathrm{k}_{2}$ & $\mathrm{R}^{2}$ & & $\mathrm{k}_{1}(\mathrm{~h})$ & $\mathrm{k}_{2}$ & $\mathrm{R}^{2}$ \\
\hline 1 & 0.291 & 0.065 & 0.911 & & 0.275 & 0.054 & 0.965 \\
2 & 0.167 & 0.032 & 0.971 & & 0.162 & 0.041 & 0.988 \\
3 & 0.278 & 0.075 & 0.849 & & 0.286 & 0.065 & 0.879 \\
4 & 0.065 & 0.024 & 0.969 & & 0.073 & 0.035 & 0.983 \\
5 & 0.255 & 0.040 & 0.864 & & 0.199 & 0.049 & 0.951 \\
6 & 0.249 & 0.022 & 0.981 & & 0.197 & 0.096 & 0.959 \\
7 & 0.207 & 0.018 & 0.926 & & 0.127 & 0.060 & 0.904 \\
8 & 0.127 & 0.015 & 0.958 & & 0.102 & 0.018 & 0.930 \\
9 & 0.094 & 0.025 & 0.954 & & 0.206 & 0.033 & 0.981 \\
10 & 0.174 & 0.029 & 0.813 & & 0.232 & 0.031 & 0.976 \\
11 & 0.400 & 0.021 & 0.983 & & 0.132 & 0.099 & 0.985 \\
12 & 0.128 & 0.012 & 0.934 & & 0.132 & 0.015 & 0.990 \\
13 & 0.083 & 0.105 & 0.880 & & 0.185 & 0.086 & 0.837 \\
14 & 0.057 & 0.038 & 0.932 & & 0.060 & 0.045 & 0.870 \\
15 & 0.214 & 0.016 & 0.929 & & 0.164 & 0.026 & 0.942 \\
16 & 0.109 & 0.026 & 0.966 & 0.111 & 0.030 & 0.922 \\
17 & 0.127 & 0.027 & 0.893 & 0.254 & 0.022 & 0.944 \\
18 & 0.160 & 0.027 & 0.948 & 0.176 & 0.026 & 0.936 \\
\hline
\end{tabular}

Table 4 shows the regression coefficients obtained for water loss (WL) and solids gain (SG) after 120 minutes of osmotic dehydration.

The adjustment of the equation for solids gain was lower than that obtained for water loss, but since the ratio of $\mathrm{F}_{\mathrm{cal}} / \mathrm{F}_{\mathrm{tab}}$ was greater than 1 , the equations were considered to be valid and were used to obtain the contour curves presented in Figure 5. According to the equations, temperature and concentration were the parameters that most influenced both water loss and solids gain, while the initial fruit:solution ratio exerted a
Table 4. Regression coefficients for water loss (WL) and solids gain (SG) after 120 minutes of osmotic dehydration

\begin{tabular}{ccl}
\hline Coefficients & WL & SG \\
\hline$\beta$ & 28.09 & 2.32 \\
$\beta_{T}$ & 5.94 & 0.39 \\
$\beta_{C}$ & 5.68 & 0.31 \\
$\beta_{F}$ & n.s. & n.s. \\
$\beta_{T T}$ & n.s. & 0.60 \\
$\beta_{C C}$ & n.s. & 0.42 \\
$\beta_{F F}$ & n.s. & n.s. \\
$\beta_{T C}$ & 4.42 & n.s. \\
$\beta_{T F}$ & -5.11 & n.s. \\
$\beta_{C F}$ & n.s. & 0.47 \\
$F_{c a l} / F_{\text {tab }}$ & 12.66 & 1.68 \\
$R^{2}$ & 0.925 & 0.685
\end{tabular}

n.s.: Not significant $(\mathrm{p}>0.05)$.

slight influence on these responses, only being significant in conjunction with the other variables.

Since osmotic dehydration is a process that generally aims at maximum water loss and minimal solids gain, the curves of these two responses were superimposed to obtain the optimum conditions for processing (Figure 5).

Figure 5 shows that water loss was maximized by increasing both temperature and solution concentration. However, one must also consider that under these conditions the structure of the star-fruit may be permanently damaged either by destructuring of the cell wall due to high temperatures or even by high sugar concentrations, which increase plasmolysis and cause cell collapse (QUILES et al., 2004). It should also be observed that an increase in solution concentration at low temperatures reduced water loss due to the increase in viscosity, as previously mentioned, which did not occur for solids gain. The smallest solids gain occurred at temperatures between 30 and $50^{\circ} \mathrm{C}$ and concentrations between 35 and $55^{\circ}$ Brix. 

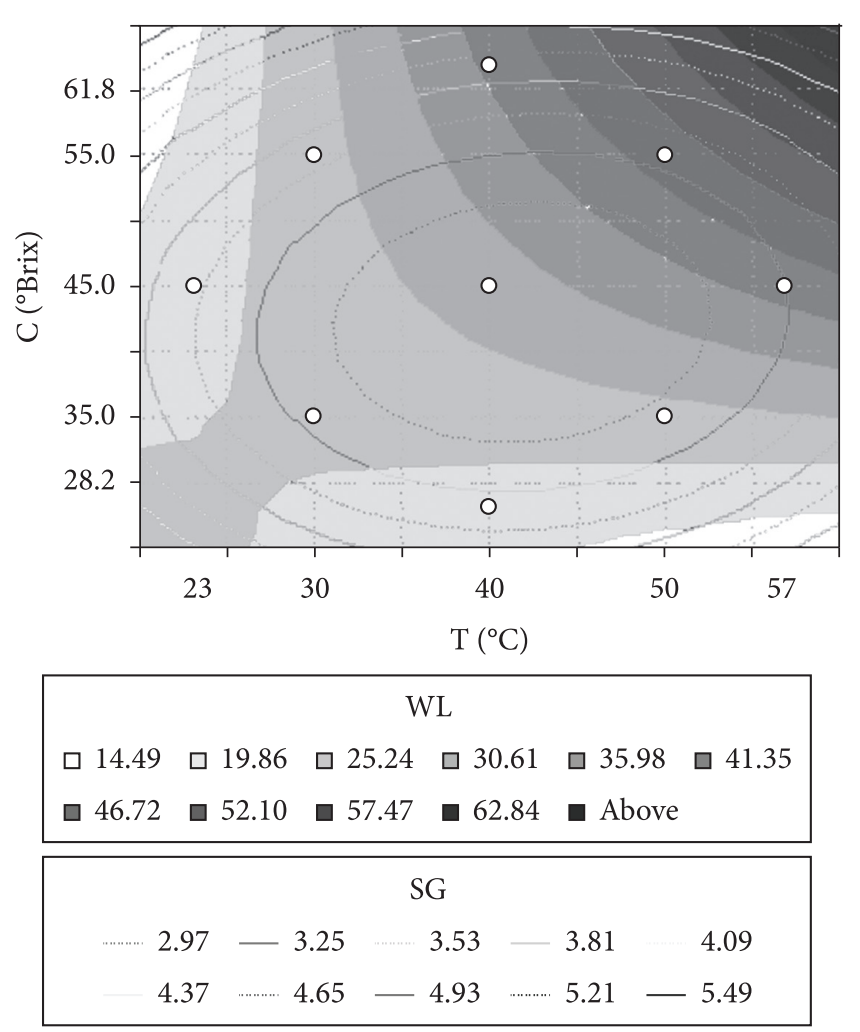

Figure 5. Superimposition of the response surfaces for water loss and solids gain for a time period of 120 minutes.

As observed in the osmotic dehydration of potato and guava (LAZARIDES; MAVROUDIS, 1996; SANJINEZARGANDOÑA; HUBINGER; MENEGALLI, 2002), the use of temperatures above $50{ }^{\circ} \mathrm{C}$ led to a loss of the cell membrane selectivity making it easier for solute to diffuse from the solution into the product. Thus, the regions on the graph showing the greatest water loss were the same as those showing the greatest solids gain. However, the ideal conditions are not those producing the greatest water loss or lowest solids gain, but rather those in which these two conditions occur simultaneously. Therefore, according to Figure 5, the conditions under which the ratio water loss/solids gain was smallest were those at temperatures close to $50^{\circ} \mathrm{C}$ and solution concentration of about $50 \%$. The initial fruit:solution ratio selected was 1:2.1 (the highest amongst all the ratios studied) since this parameter exerted little influence on the process, and the solution is generally discarded after use.

In order to validate the model obtained, both water loss and solids gain were determined experimentally after 120 minutes of process under the optimum conditions selected in the experimental design (temperature of $50^{\circ} \mathrm{C}$, solution concentration of $50 \%$, and initial fruit:solution ratio of 1:2.1). The experimental results as well as those predicted by the model can be seen in Table 5 .

According to Table 5, the difference between the predicted and experimental values was small, especially for water loss. The higher relative error calculated for solids gain is related with the lower determination coefficient $(0.685)$ for this response, which indicates a poorer fit of the model to the experimental data.
Table 5. Experimental and predicted values for water loss (WL) and solids gain (SG) for star-fruit osmotically dehydrated for 120 minutes at $\mathrm{T}=50^{\circ} \mathrm{C}, \mathrm{C}=50^{\circ} \mathrm{Brix}$ and $\mathrm{F}: \mathrm{S}$ ratio of $1: 2.1$

\begin{tabular}{cccc}
\hline Response & Experimental value & Predicted value & Relative error $(\%)$ \\
\hline $\mathrm{WL}(\% \mathrm{~m} / \mathrm{m})$ & 32.98 & 30.50 & 7.52 \\
$\mathrm{SG}(\% \mathrm{~m} / \mathrm{m})$ & 3.38 & 3.96 & 14.65 \\
\hline
\end{tabular}

Table 6. Luminosity $\left(\mathrm{L}^{*}\right)$ and the total color variation $\left(\Delta \mathrm{E}^{*}\right)$ of the samples subjected and those that were not subjected to blanching. ${ }^{a}$ significant difference in relation to the in natura fruit $(\mathrm{p}<0.05)$.

\begin{tabular}{lccc}
\hline & In & \multicolumn{2}{c}{ After 120 minutes } \\
\cline { 3 - 4 } & natura & Blanched & Not blanched \\
\hline $\mathrm{L}^{\star}$ & 58.76 & 59.25 & $57.23^{\mathrm{a}}$ \\
$\Delta \mathrm{E}^{\star}$ & - & 1.60 & 8.82 \\
\hline
\end{tabular}

\section{Effect of blanching on the final color of osmotically dehydrated star-fruit}

In order to evaluate the influence of blanching on the starfruit color after the osmotic dehydration process, instrumental color analyses were carried out on the fruit slices dehydrated under the optimized process condition (temperature of $50{ }^{\circ} \mathrm{C}$, solution concentration of $50 \%$, and initial fruit:solution ratio of 1:2.1) after 120 minutes of processing. The results obtained for the fruits subjected and those that were not subjected to the blanching condition determined in item 3.1 were compared (Table 6).

The samples subjected to blanching presented higher luminosity values $\left(L^{\star}\right)$ than the non-blanched fruits. When compared to the fresh sample, the blanching treatment led to a slight, although not significant ( $p>0.05)$, increase in luminosity, which could be related to the increase in the fruits brightness due to the entrance of sugars. On the other hand, the results showed that processing led to a decrease in the $\mathrm{L}^{*}$ value in the non-blanched fruits $(p<0.05)$ indicating browning of the fruit during processing.

The effect of blanching on the color of the osmotically dehydrated star-fruit can be better evaluated from the total color variation $\left(\Delta \mathrm{E}^{*}\right)$ in relation to the fresh fruit. In this case, the pretreatment in a $0.75 \%$ citric acid solution for 15 minutes before osmotic dehydration led to a $\Delta \mathrm{E}^{*}$ value 5 times smaller than the non-treated star-fruit. This result shows that blanching was efficient in maintaining the color of the osmotically dehydrated star-fruit.

\section{Conclusions}

Osmotic dehydration of star-fruit was more effective in the first two hours of processing. After this period, the process started to show smaller mass transfer rates.

Temperature had a positive influence on water and solids diffusivity resulting in greater water loss and solids gain. The increase in solution concentration led to an increase in solids gain but, at certain temperatures at which there was an increase in solution viscosity, it hindered water loss. The initial fruit:solution rate exerted little influence on the process.

The osmotic dehydration carried out at $50^{\circ} \mathrm{C}$ with solution concentration of $50 \%$ resulted in lower solids gain and greater 
water loss, and these were selected as the optimum process conditions. Since the initial fruit:solution ratio had little influence on the water loss and solids gain rates, the ratio of 1:2.1 was selected for being economically more interesting.

Blanching of the star-fruit in $0.75 \%$ citric acid represented the best cost:benefit ratio when compared with combinations of this acid with ascorbic acid, and it was effective in maintaining the color of the osmotically dehydrated fruit.

\section{Acknowledgements}

The authors are grateful to SAE (Serviço de Apoio ao Estudante - UNICAMP), CNPq and FAPESP for the financial support.

\section{References}

ALZAMORA, S. M. et al. Structural changes in the minimal processing of fruits: Some effects of blanching and sugar impregnation. In: FITO, P.; ORTEGA-RODRIGUES, E.; BARBOSA-CANOVAS, G. (Ed.). Food engineering 2000. New York: Chapman \& Hall, 1997. cap. 8, 117-139.

ASSOCIATION OF OFFICIAL ANALYTICAL CHEMISTS - AOAC. Official Methods of Analysis. 16th ed. Arlington: AOAC, 1995.

ATARÉS, L.; CHIRALT, A.; GONZÁLEZ-MARTÍNEZ, C. Effect of solute on osmotic dehydration and rehydration of vacuum impregnated apple cylinders (cv. Granny Smith). Journal of Food Engineering, v. 89, n.1, p. 49-56, 2008. http://dx.doi.org/10.1016/j. jfoodeng.2008.04.002

AZOUBEL, P. M.; MURR, F. E. X. Mass transfer kinetics of osmotic dehydration of cherry tomato. Journal of Food Engineering, v. 61, n. 3, p. 291-295, 2004. http://dx.doi.org/10.1016/S0260-8774(03)00132-8

BAUCHOT, A. D. et al. Cell wall properties of kiwifruit affected by low temperature break down. Postharvest Biology and Technology, v.16, n. 3, p. 245- 255, 1999. http://dx.doi.org/10.1016/S09255214(99)00016-2

BETORET, N. et al. Kinetics of osmotic dehydration of cassava (Manihot esculenta crantz) slices: influence of temperature and sodium chloride concentration. In: INTERNATIONAL CONGRESS ON ENGINEERING AND FOOD, 9., 2004, Montpellier. Proceedings... Montpellier: International Association for Engineering and Food, 2004. p. 7-11.

CHENLO, F. et al. Viscosities of aqueous solutions of sucrose and sodium chloride of interest in osmotic dehydration processes. Journal of Food Engineering, v. 54, n. 4, p. 347-352, 2002. http:// dx.doi.org/10.1016/S0260-8774(01)00221-7

CUSSLER, E. L. Diffusion mass transfer in fluid systems. New York: Cambridge University Press, 1997. 580 p.

FERNANDES, F. A. N. et al. Optimization of osmotic dehydration of bananas followed by air-drying. Journal of Food Engineering, v. 77, n. 1,p. 188-193, 2006. http://dx.doi.org/10.1016/j.jfoodeng.2005.05.058

FERRARI, C. C. et al. Cinética de transferência de massa de melão desidratado osmoticamente em soluções de sacarose e maltose. Ciência e Tecnologia de Alimentos, v. 25, n. 3, p. 564-570, 2005. http://dx.doi.org/10.1590/S0101-20612005000300028

LAZARIDES, H. N.; MAVROUDIS, N. E. Kinetics of osmotic dehydration of a highly shrinking vegetable tissue in a salt-free medium. Journal of Food Engineering, v. 30, n. 1-2, p. 61-74, 1996. http://dx.doi.org/10.1016/S0260-8774(96)00042-8

LENART, A. Osmo-convective drying of fruits and vegetables: technology and application. Drying Technology, v.14, n. 2, p. 391-413, 1996. http://dx.doi.org/10.1080/07373939608917104
MANO-FRANCIS, I.; BADRIE, N. Effects of brining pretreatment and storage on carambola (Averrhoa carambola L.) pickles. Journal of Food Processing and Preservation, v. 28, n. 1, p. 51-67, 2004. http://dx.doi.org/10.1111/j.1745-4549.2004.tb00537.x

MATUSEK, A.; CZUKOR, B.; MERESZ, P. Comparison of sucrose and fructo-oligosaccharides as osmotic agents in apple. Innovative Food Science \& Emerging Technologies, v. 9, n. 3, p. 365-373, 2008. http://dx.doi.org/10.1016/j.ifset.2007.10.003

PARK, K. J. et al. Osmotic dehydration kinetics of pear D'anjou (Pyrus communis L.). Journal of Food Engineering, v. 52, n. 3, p. 293-298, 2002. http://dx.doi.org/10.1016/S0260-8774(01)00118-2

PELEG, M. An empirical-model for the description of moisture sorption curves. Journal of Food Science, v. 53, n. 4, p.1216-1219, 1988. http://dx.doi.org/10.1111/j.1365-2621.1988.tb13565.x

PEREIRA, L. M.; CARMELLO-GUERREIRO, S. M.; HUBINGER, M. D. Microscopic features, mechanical and thermal properties of osmotically dehydrated guavas. LWT - Food Science and Technology, v. 42, n.1, p.378-384, 2009.

PÉREZ-TELLO, G. O. et al. Effect of temperature on enzymatic and physiological factors related to chilling injury in carambola fruit (Averrhoa carambola L.). Biochemical and Biophysical Research Communications, v. 287, n. 4, p. 846-851, 2001. PMid:11573941. http://dx.doi.org/10.1006/bbrc.2001.5670

QUILES, A. et al. The effect of calcium and cellular permeabilization on the structure of the parenchyma of osmotic dehydrated 'Granny Smith' apple. Journal of the Science of Food and Agriculture, v. 84, n.13, p.1765-1770, 2004. http://dx.doi.org/10.1002/jsfa.1884

QUINTAS, M. et al. Rheology of supersaturated sucrose solutions. Journal of Food Engineering, v.77, n. 4, p. 844-852, 2006. http:// dx.doi.org/10.1016/j.jfoodeng.2005.08.011

RAOULT-WACK, A. L. Recent advances in the osmotic dehydration of foods. Trends in Food Science \& Technology, v. 5, n. 8, p. 255-260, 1994. PMid:21299575. http://dx.doi.org/10.1016/09242244(94)90018-3

SANJINEZ-ARGANDOÑA, E. J. Desidratação osmótica de goiaba por imersão e secagem. Campinas, 1999. 102 f. Dissertação (Mestrado em Engenharia de Alimentos)- Faculdade de Engenharia de Alimentos, Universidade Estadual de Campinas, Campinas, 1999.

SANJINEZ-ARGANDONAA, E. J.; HUBINGER, M. D.; MENEGALLI, F. C. Effect of osmotic dehydration on colour and mechanical properties of dried guavas. In: INTERNATIONAL DRYING SYMPOSIUM, 13., 2002, Beijing. Proceedings... Beijing, 2002. v. B, p. $968-976$.

SHIGUEMATSU, E. et al. Influência de pré-tratamentos sobre a desidratação osmótica de carambolas. Ciência e Tecnologia de Alimentos, v. 25, n. 3, p. 536-545, 2005.

SOUSA, P. H. M. et al. Influência da concentração e da proporção fruto:xarope na desidratação osmótica de bananas processadas. Ciência e Tecnologia de Alimentos, v. 23, p. 126-130, 2003. Suplemento. http://dx.doi.org/10.1590/S0101-20612003000400024

TELES, U. M. et al. Optimization of osmotic dehydration of melons followed by air-drying. International Journal of Food Science and Technology, v. 41, n. 6, p. 674-680, 2006. http://dx.doi.org/10.1111/ j.1365-2621.2005.01134.x

TORREGIANI, D. Osmotic dehydration in fruit and vegetable processing. Food Research International, v. 26, n.1, p. 59-68, 1993. http://dx.doi.org/10.1016/0963-9969(93)90106-S

UDDIN, M. B.; AINSWORTH, P.; IBANOGLU, S. Evaluation of mass exchange during osmotic dehydration of carrots using response surface methodology. Journal of Food Engineering, v. 65, n. 4, p. 473-477, 2004. http://dx.doi.org/10.1016/j.jfoodeng.2004.02.007

WELLER, A. et al. Browning susceptibility and changes in composition during storage of carambola slices. Journal of Food Science, v. 62, n. 2, p. 256-260, 1997. http://dx.doi.org/10.1111/j.1365-2621.1997.tb03980.x 